ential coloring that will make mycelium stand out in contast to the tissue of the host have been described. ${ }^{1}$

The writers, in an attempt to obtain a stain which would reduce the time required for the examinations of a set of woods infected with molds by producing satisfactory differentiation both for visual examination and for photomicrography, have worked out the following method. The results, although the work is only in the preliminary stage, are so promising that they are given here in order that others may avail themselves of the method if they desire to do so.

Since there is a difference in chemical composition between wood substance and chitin or "fungous cellulose," the assumption was made that the fungous mycelium might possess characteristic mildly oxidizing or reducing properties. Then a solution of silver nitrate in distilled water was applied to thin sections of the infected wood. These were allowed to stand for periods of various lengths, overnight staining giving a very satisfactory result. The sections were then examined directly or dehydrated with alcohol, cleared with xylol, and mounted in Canada balsam. Drying the balsam mounts under weights in an oven over night appeared, if anything, to improve the stain secured.

Both conifers and hardwoods were treated in this way. The mycelium of several molds and of two wood-destroying fungi has thus far been stained. In all cases the mycelium was differentiated by its blackish brown, purplish brown, or orange color. The wood tissue presented, if stained, a lighter shade of yellowish brown against which the mycelium was readily visible, often under relatively low magnifications.

Silver nitrate solution also gave interesting staining of the wood structures and cell contents which will be discussed at some future time.

Gold chloride solution, and the "Berlin Blue" stain, the latter as described by Dr. Sophia Eckerson in her course in microchem-

1 Sinnott, E. W. and I. W. Bailey, Phytopath., 4: 403, 1914. Vaughan, R. E., Ann. Mo. Bot. Gard., $5: 241,1914$ and others. istry, ${ }^{2}$ were also used with some success for the same purposes as the silver nitrate.

M. E. Diemer,
Chemist,
Eloise Gerry,
Microscopist
Forest Products Laboratory,
U. S. DePartment OF Agriculture,
Madison, Wisconsin

\section{SHARKS AT SAN DIEGO}

To the Euitor of Science: It has occurred to the writer that a very brief statement of some experiences in collecting shark material at San Diego, Cal., in 1920-21 might be of value to persons interested in research problems in elasmobranch morphology and embryology. Owing to the fact that the reduction plants in San Diego paid in 1920-21 a price for sharks high enough to make it worth while for the fishermen to bring in all such material caught incidentally, and since nearly all such material was brought to the fishmarket pier, at the latter place it was possible in a very short time to collect a considerable range of species. The writer obtained twentysix species of elasmobranchs at San Diego, and the embryos of fourteen of them. No other place along the Pacific coast, or probably on any other coast, offers such a wealth of material and such easy access to it. It was not uncommon to see fifteen species of elasmobranchs at one time on the pier at San Diego.

H. W. NoRRIS

\section{GrinNell College}

\section{MUNICIPAL OBSERVATORIES}

To the Editor of Science: In Solence for August 5, the Municipal Observatory at Des Moines is "said to be the only municipal observatory in the world." The Cincinnati Observatory was incorporated in 1842, its corner stone being laid in 1843 by John Quincy Adams. Here Cleveland Abbe (director '68-'73) first issued daily weather reports and laid the foundation of the U. S. Weather Bureau. In 1872, the property was transferred to the University of Cincinnati (municipal) on condition that the city sup-

2 Text-book now in preparation. 
port the observatory, which has since been done. The observatory now receives by law the income of a tax levy of one twentieth of a mill.

Nevin M. Fenneman

UnIVERSiTy of Cincinnati, December 2, 1921

\section{SCIENTIFIC BOOKS THE ORDER OF NATURE}

The Principles of Natural Knowledge, by A. N. Whitehead, Cambridge University Press, 1919.

L'Unité de la Science, by Leclerc du Sablon. Félix Alcan, Paris, 1919.

The Order of Nature, by Lawrence J. Henderson. Harvard University Press, 1917.

The System of Animate Nature, by J. A. Thomson. Two volumes. Williams and Norgate, London, 1920.

In the first dialogue between Hylas and Philonous Berkeley has the latter to say: "I am not for imposing any sense on your words: you are at liberty to explain them as you please. Only, I beseech you, make me understand something by them." The author of "The Principles of Natural Knowledge" has obviously had before him not only this demand, which he sets forth by giving the foregoing quotation on his title-page, but also the further one that every intelligent reader shall understand the same things by his words. Neither of these ideals is easily realized in philosophical writings; and this is most emphatically true of those which are addressed to readers not interested in the technical aspects of philosophy. Why does this diffculty exist? "We have to remember that while nature is complex with timeless subtlety, human thought issues from the simplemindedness of beings whose active life is less than half a century."

The author seeks to realize clarity by the so-called "method of logical atomism" which "has gradually crept into philosophy through the critical scrutiny of mathematics" and in his discussion to substitute "piecemeal, detailed and verifiable results for large untested generalities recommended only by a certain appeal to the imagination," to use Bertrand Russell's characterization of the philosophy of logical atomism. Whitehead analyzes thought into elements which the unsophisticated mind could never recognize as parts of its original thought content; and sometimes even for the expert, one must believe, there is real difficulty in putting together the parts so as to recover the whole. But the reader is not in doubt as to what the author says or what he means. Whitehead says:

"The fundamental assumption to be elaborated in the course of this enquiry, is that the ultimate facts of nature, in terms of which all physical and biological explanation must be expressed, are events connected by their spatio-temporal relations, and that these relations are in the main reducible to the property of events that they contain (or extend over) other events which are parts of them." Time is not a succession of instants. but a complex of interlocking events, each helping to tie the others to the past and the future. "The conception of the instant of time as an ultimate entity is the source of all our difficulties of explanation.... Our perception of time is as a duration."

The work as a whole contains a somewhat technical and rather disjointed analysis of four matters, namely: the traditions of science; the data of science; the method of extensive abstraction; the theory of objects. The book will have its greatest appeal to the reader of considerable mathematical maturity, even though it does not at all depend on mathematical detail; for the point of view is evidently taken in the light of the recent philosophy of mathematics.

In "L'Unité de la Science" by M. Leclerc du Sablon we have an equal clarity, but it differs from that of Whitehead's work in being strongly marked by French characteristics.

In his preface Whitehead says: "In matters philosophic the obligations of an author to others usually arise from schools of debate rather than from schools of agreement. Also such schools are the more important in pro- 